\title{
CHEMICAL COMPOSITION OF PALEOZOIC ROCKS FROM NORTHERN KISO DISTRICT AND OF TOYOMA CLAYSLATES IN KITAKAMI MOUNTAINLAND: SUPPLEMENT. CARBON AND CARBON DIOXIDE
}

\author{
Masato Katada, Hiroshi Isomi, Ei OMori \\ and TeIKo Yamada
}

Geological Survey of Japan, Kawasaki

\section{INTRODUCTION}

Our two reports on the chemical composition of the Paleozoic rocks were already published in the former issues of this journal. The present short paper, as a supplement to them, deals with carbon as well as $\mathrm{CO}_{2}$ of the same samples. The analyses are shown in table $10^{*}$.

The authors express their deep gratitude to Prof. Y. Kawano of the Tohoku University, Asst. Prof. A. Miyashiro of the Tokyo University, Mr. T. Hamachi, Mr. N. Andô and Mr. K. Ono of the Geological Survey of Japan for their instructive suggestions and criticisms.

\section{CARBON}

Correlation of carbon content with the kinds of rocks

In clarifying this problem, effects of the metamorphism must be excluded as much as possible. For this reason, only the chemical analyses of non- or nearly non-metamorphosed rocks are examined at this time.

* Carbon is determined by gravimetry: $0.3 \sim 0.5 \mathrm{~g}$ powder sample is heated stlongly in the oxigen flow. Carbon dioxide oxidized from carbon is absorbed in the natronasbest and is weighted.

Carbon dioxide is determined by volumetry: carbon dioxide evolved by the addition of enough acid to the $0.5 \mathrm{~g}$ powder sample is absorbed in the baryta water and is titrated.

(Manuscript received, August, 1964) 
Carbon* in question is organic substance mainly of plantorigin. It is actually, though not frequently, observed that thin layers or mere lamina crowded with carbonized fragments of plants are contained in fine-grained sandstone or siltstone. Such abnormal case is represented by the sample no. 22 on table 10 , a fine-grained sandstone. The content of carbon in no. 22 attains to $2.13 \%$, several times as high as ordinary sandstone of the same grain-size.

In the six samples of the non-metamorphosed clayslate, carbon amounts to $1.55 \%$ on average. It becomes much smaller in the two analysed samples of the ordinary fine-grained sandstone, the value being $0.25 \%$ in no. 20 and $0.42 \%$ in no. 21 . The content sinks down much more in the two analyses of the coarse-grained sandstone, and the value drops to $0.14 \%$ in no. 23 and to $0.13 \%$ in no. 25 . Therefore, it can be concluded that carbon content of the clastic sediments shows a general tendency to decrease with rise of grainsize grade. Cherty mudstone tends to include less carbon content than the normal non-cherty ones. It is hardly found in the analysis no 11, a representative of the typical cherty mudstone. And it is only $0.23 \%$ in the slightly cherty mudstone no. 7 .

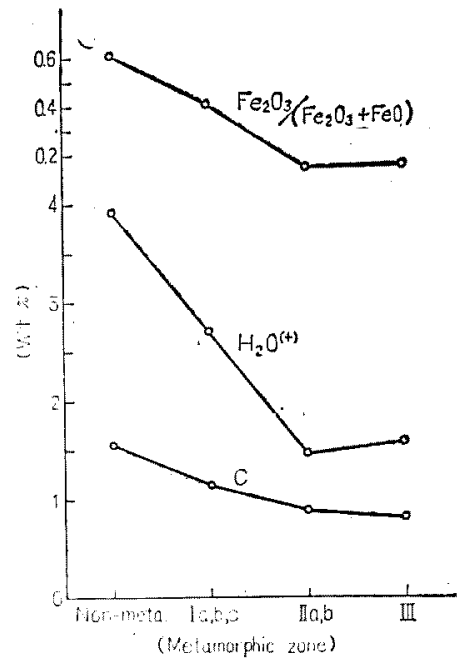

Table 11. Average content of carbon in clayslate of each metamorphic zone.

\begin{tabular}{c|c|c}
\hline & Carbon & Sample no. \\
\hline Non-meta. zone & 1.55 & $1 \sim 6$ \\
Zone I & 1.14 & $7 \sim 11$ \\
Zone II & 0.84 & $12 \sim 15$ \\
Zone III & 0.82 & $16 \& 17$ \\
\hline
\end{tabular}

$\leftarrow$ Fig. 7. Relations of metamorphic grade with $\mathrm{Fe}_{2} \mathrm{O}_{3} /\left(\mathrm{Fe}_{2} \mathrm{O}_{3}+\right.$ $\mathrm{FeO})$ ratio, $\mathrm{H}_{2} \mathrm{O}(+)$ and carbon content.

* Carbonaceous matter in non- and low-graded metamorphic zones retains the original structure of the organic body, and pure graphite is hardly ascertained under the ore-microscope. Carbonaceous matter is changed into pure graphite in high-grade metamorphic zone, and the graphite crystal shows the bended lath-shaped outline. 
Table 10. Carbon and carbon dioxide of Paleozoic rocks.

\begin{tabular}{|c|c|c|c|c|c|c|c|c|c|c|c|c|c|c|c|c|c|c|c|c|c|c|c|c|c|c|c|c|c|c|}
\hline \multirow{2}{*}{$\begin{array}{l}\text { Rock type } \\
\text { Sample no. } * 1\end{array}$} & \multicolumn{17}{|c|}{ Clayslate } & \multicolumn{2}{|c|}{$\left(\begin{array}{c}\text { Toyoma } \\
\text { formation }\end{array}\right)$} & \multicolumn{3}{|c|}{$\begin{array}{l}\text { Fine-grained } \\
\text { sandstone }\end{array}$} & \multicolumn{3}{|c|}{$\begin{array}{l}\text { Coarse-grained } \\
\text { sandstone }\end{array}$} & \multicolumn{2}{|c|}{$\begin{array}{l}\text { Highly meta. } \\
\text { coarse-grained } \\
\text { sandston }\end{array}$} & \multicolumn{3}{|c|}{ Basalt } \\
\hline & 1 & 2 & 3 & 4 & 5 & 6 & 7 & 8 & 9 & 10 & 11 & 12 & 13 & 14 & 15 & 16 & 17 & 18 & 19 & 20 & 21 & 22 & 23 & 24 & 25 & 26 & 27 & 28 & 29 & 30 \\
\hline Carbon & 1.51 & 0.70 & 1.04 & 2.06 & 1.83 & 2.16 & 0.23 & 0.70 & 1.75 & 0.96 & - & 0.80 & 0.64 & 1.54 & 0.58 & 0.96 & 0.67 & 0.41 & 0.35 & 0.25 & 0.42 & 2.13 & 0.14 & n.d. & 0.13 & 0.16 & 0.64 & 0.16 & - & - \\
\hline $\mathrm{CO}_{2}$ & - & - & - & - & - & - & - & - & - & - & - & - & - & - & - & - & - & - & - & - & 0.93 & - & 2.13 & n. d. & 3.49 & - & - & 1.44 & 0.05 & 0.88 \\
\hline Total*2 & $99.87 * 3$ & 99.60 & 99.83 & 99.78 & 99.84 & 99.51 & $99.79 * 4$ & 99.72 & 99.93 & 100.24 & 99.78 & 99.97 & 99.95 & 100.11 & 99.72 & 100.12 & 100.08 & 100.19 & 99.79 & 99.92 & 100.18 & 100.23 & 99.64 & 97.02 & 99.52 & 100.14 & 99.52 & 99.85 & 99.60 & 99.71 \\
\hline
\end{tabular}

* 1. Sample no. of this table corresponds with that of table 1 and table 5 of the previous papers.

* 2. Total including carbon and $\mathrm{CO}_{2}$

* 3. "Total" (excluding carbon and $\mathrm{CO}_{2}$ ) of no. 1 on the table 1 is misprinted. It is 98.36 in place of 99.36.

* 4. "Total" of no. 7 's also misprinted, 99.56 in place of 99.59 . 
Chemical composition of Paleozoic rocks from northern Kiso district 219

\section{Loss of Carbon due to metamorphism}

The problem of loss of carbon depending upon metamorphic grade can be clarified on the clayslates of which 17 chemical analyses are made. The averaged carbon content of the clayslate in each metamorphic zone is given in table 11. These values are plotted on figure 7. It is obvious from a glance at the figure that the carbon content tends to decrease with rise of metamorphic grade.

Besides, the ratio of $\mathrm{Fe}_{2} \mathrm{O}_{3} /\left(\mathrm{Fe}_{2} \mathrm{O}_{3}+\mathrm{FeO}\right)$ and the content of $\mathrm{H}_{2} \mathrm{O}$ have - as was already remarked in our previous paper (1963a, p. 98) - the same tendency as carbon. In order to display such tendencies, both values are also plotted in figure 7 .

From these considerations, decrease of carbon and reduction of ferric iron* seem to be mutally related with cach other, both being the effects of rising metamorphic grade. This is not a new finding at all, but has been widely recognized. For example, Pettijohn described (1956, p. 346) in his textbook: "Presumably some of the organic matter is lost as $\mathrm{CO}_{2}$ as a result of reduction of the ferric iron".

Such view can be indicated by the following equation;

$$
\mathrm{C}+2 \mathrm{Fe}_{2} \mathrm{O}_{3}=\mathrm{CO}_{2}+4 \mathrm{FeO} \text {. }
$$

It is not meaningless to examine, on the actual results of our chemical analyses, the problem whether the loss of carbon can be completely explained only by the reaction or not. For the sake of calculation, we take, in place of the absolute content in each metamorphic grade, the difference of content between two metamorphic grades next to each other. The change of chemistry in question is negligible from the metamorphic grade zone II to III. And we have only two analyses concerning to the zone III, its information being too poor. For these reasons, the zone III is left out of our consideration.

From the value of increase of $\mathrm{FeO}(\mathrm{a})$, the carbon content (b) which is to be lost as $\mathrm{CO}_{2}$, can be calculated after the equation. The result is shown in table 12 . This value thus calculated is com-

* Total iron as $\mathrm{Fe}_{2} \mathrm{O}_{3}$ of the clayslates is almost constant throughout all metamorphic zones. It is $5.88 \%$ in the non-metamorphic zone, $5.64 \%$ in the zone I, 5.70\% in the zone II and 6.10\% in the zone III. Therefore, the content of total iron is essentially independent of the metamorphic grade.

The iron in question is included in both ore minerals and ferromagnesian silicate minerals. According to the volumetrical measurements, the volume percentage of ore minerals, ilmenite, pyrrhotite and chalcopyrite, is in the clayslate usually $0.5 \sim 2 \%$. In other words, the weight percentage of ore minerals is about $1 \sim 4 \%$. 
Table 12.

\begin{tabular}{c|c|c|c|c|c}
\hline & $(\mathrm{a})$ & $(\mathrm{b})$ & $(\mathrm{c})$ & (d) & (e) \\
\cline { 2 - 6 } & $\begin{array}{c}\text { Actual increase } \\
\text { of FeO }\end{array}$ & $\begin{array}{c}\text { Calculated } \\
\text { decrease } \\
\text { of carbon }\end{array}$ & $\begin{array}{c}\text { Actual decrease } \\
\text { of carbon }\end{array}$ & (b)/(c) & (c)-(b) \\
\hline $\begin{array}{c}\text { Non-meta. zone } \\
\rightarrow \text { Zone I }\end{array}$ & 0.92 & 0.04 & 0.41 & 0.1 & 0.37 \\
\hline $\begin{array}{c}\text { Zone I } \\
\rightarrow \text { Zone II }\end{array}$ & 1.31 & 0.05 & 0.25 & 0.2 & 0.20 \\
\hline
\end{tabular}

(a) (b) (c) \& (e) : wt 96. (d) : Ratio.

pared with the value of actual loss of carbon indicated by our chemical analyses.

It is evident from the comparison of (b) and (c) in the table that the loss of carbon related with reduction is by far less than the actual loss. The former occupies only $10 \sim 20 \%$ of the latter (d). In other words, most parts of the lost carbon cannot be explained after the equation.

In consequence, it is evident that more than $80 \%$ of the decreased carbon is related with chemical reactions other than the reduction of iron, though only a small part of the lost carbon is believed to be the direct effect of the reduction of iron.

\section{Less content of carbon in the Toyoma clayslates}

Carbon content of the Toyoma clayslate is by far less than the clayslates from the Kiso mountains. This fact is the very reverse to the usual expectation. It's remarkable blackness is not due to the presence of carbonaceous matter, but is presumably connected with the charactenstic nature that it contains more iron ores of fereous state. The averaged content of $\mathrm{FeO}$ attains to $4.53 \%$, while the content in the clayslates from Kiso is $3.40 \%$ on average.

From the geological viewpoint there is no reason to think that the primary deposits in the sedimentary basin contained less carbon than usual. One of the causes for its low content of carbon may be the intense reduction of ferric iron; its $\mathrm{Fe}_{2} \mathrm{O}_{3} /\left(\mathrm{Fe}_{2} \mathrm{O}_{3}+\mathrm{FeO}\right)$ ratio is only 0.32 on average, being lower than the clayslates from Kiso. The ratio of the Kiso clayslates is 0.61 in the case of the non-metamorphic one, and 0.41 even in the case of the metamorphic zone I.

After all, it is very probable that reduction of ferric iron and escape of carbon by oxidation in the Toyoma claysaltes more proceeded during the para-sedimentary or early diagenetic stage 
than in the Kiso clayslates.

\section{Carbon Dioxide}

$\mathrm{CO}_{2}$, combined with $\mathrm{CaO}$ or $\mathrm{MgO}$, form carbonates, either calcite or dolomite. Inthe sandstone, $\mathrm{CO}_{2}$ is found by chemical analyses. Microscopic observation proves that a small quantity of carbonates are contained as clastic grain in the coarse-grained sandstones.

For the clayslates, the matter is quite different. Our chemical analyses of the clayslates scarcely indicates $\mathrm{CO}_{2}$. Presence of carbonates can not be ascertained under microscope as well. Therefore, in the clayslates, most parts of $\mathrm{CaO}$ content are believed to be present not as carbonates but as plagioclase.

\section{REFERENCES}

Banno, S, and K. Kanehira (1961), Sulfied and oxide minerals in schists of the Sanbagawa and central Abukuma metamorphic terranes, Japan. Jour. Geol. Geogr., 32, 331-348.

Pettijohn, F.J. (1957), Sedimentary rocks, 2nd ed., Harpara \& Brothers, New York.

Miyashiro, A. (1964), Oxidation and reduction in the Earth's crust with special reference to the role of graphite, Geoch. Cosmoch. Acta, 28, 717-729.

\section{北部木雷地方の古生層および北上山地 \\ 登米層の粘板岩の化学成分 (III)}

$$
\begin{aligned}
& \text { 片田正人・礒見博 - } \\
& \text { 大森えい山田貞子 }
\end{aligned}
$$

摘 要

標題の報文の最後として, carbon と $\mathrm{CO}_{2}$ の分析値を示した。

Carbonは，粗粒の堆䅡岩より，細粒のものに多く含まれる。領家変成作用をうけたも のでみると，高変成度の岩石ほと含有量が小さい。おそらく逸散したものであろう。Carbon の酸化・逸散と，鉄の阌元との関係は，よく言われる所であるが，实際の分析值か らみると，Carbon の冕散の原因のうちでは，铁の還元は，こく一部の現象にすぎい。

登米層の粘板岩の Carbon は，木曾地方の（非変成の）粘板岩のものより少量である。 この場合は，おそらく鉄の還元が関係しているのであうう。

$\mathrm{CO}_{2}$ は，炭酸塩鉱物を形成している。ただ，粘板岩中ては稀である。 